\title{
Impact of Big Five Personality traits of Influencers on Positive Word of Mouth and Consumer buying decision: An empirical study among consumers
}

\author{
Ms. Pallavi Jaggi \& Prof. (Dr.) B.B. Goyal \\ University business school, Panjab University, Chandigarh
}

\begin{abstract}
:
Purpose - The research seeks to investigate the role of the big five personality traits of influencers on positive Word of Mouth (WOM) and consumer buying decisions.

Design/methodology/approach - The research question is examined using Convenience sampling which is a type of non-probability sampling technique. Respondents filled the online questionnaire between November 2020 to October 2021. The data were collected through online questionnaires which were circulated through Google forms on various social networking sites to a sample of 500 respondents, out of which 300 responses were valid. Structured questionnaires are used in this study to collect quantitative data. Statistical analysis, such as correlation and regression through SPSS Statistics, have been used to obtain the relationship between variables.
\end{abstract}

Findings - Key findings indicates the ability of the influencers who are open to new experiences and extraverts are likely to share positive WOM which ultimately leads to consumer buying decisions. Emotions like excitement also create awareness among people to share positive WOM. Excited influencers tend to try and buy new brands leading to recommending the consumers.

Research limitations- There is a need to extend the results to large sample size and diverse range of cultures.

Practical implications - The influencers on various social media platforms should build up confidence among people by conducting various activities and making them feel connected with a particular brand or product. They should try to create excitement by suitable designs in their products. Word of mouth will reduce the marketing expenses of a company.

Keywords: Big five personality traits, Positive word of mouth, Influencers, Emotions, Consumer Buying Decision 


\section{Introduction:}

Word of Mouth (WOM) is a communication between people who share their opinions about the experience regarding a particular product or service. Word of mouth is particularly valuable for the consumer's services as it reduces their perceived risk in making a purchase decision (Ennew, C., Bauerjee, A.K., Li, D. 2000). As consumers are getting rich, there is a shift from commodity-based consumption to experience-based consumption (Back, K. J. 2005). Word of Mouth is informal advice (East, R. (2009) shared between consumers. It is considered a powerful force affecting consumers' attitudes and beliefs (Vazquez-Casielles, R., SuarezAlvarez, L., \& del Río-Lanza, A. B. 2013). It is treated as the superman of media as it is free and powerful. Using Word of Mouth (WOM) marketing helps build positive feelings about a product or service which in turn, helps in building the company's brand.

Word of Mouth (WOM) has gained importance due to socialization and interaction between different members of society. It is considered as a customer-to-customer (C2C) interaction as they share their opinions and experiences (Libai, B., Bolton, R., Bugel, M. S., De Ruyter, K., Gotz, O., Risselada, H., \& Stephen, A. T. 2010). Marketing literature has shown personal influences have a great impact on consumer buying decisions. Opinions by other consumers have a significant impact on consumer buying decisions. This communication process is more effective than traditional marketing. It is one of the consumer-driven approaches (Casielles et. al 2013).

The term Word of Mouth (WOM) is emerging in different fields and it is effective in the marketing and media sector (Casielles et. al 2013), university preferences (Ozdemira, A., Tozlub, E., Şenc, E., \& Ateşoğlud, H. 2016), restaurant industry (Jalilvand, M. R., Salimipour, S., Elyasi, M., \& Mohammadi, M. 2017), movie industry (Archer-Brown, C., Kampani, J., Marder, B., Bal, A. S., \& Kietzmann, J. 2017). Lim, B. C., \& Chung, C. M. (2011) concluded that the extent of literature in the field of Word of Mouth (WOM) is limited as compared to areas like advertising on consumers. It is a cost-effective and more reliable source of sharing information. WOM plays an important role in shaping the attitudes of consumers. Consumers tend to rely on Word of Mouth (WOM) for getting familiar with the products. Brand increases the trust and asset value of any company (Yasin et.al 2013).

Previous research has addressed several aspects of Word of Mouth (WOM): attribute evaluation (Chung et.al 2011), customer to customer interaction (Stephen et. al 2010), consumer buying decision (Ahmad, N., Vveinhardt, J., \& Ahmed, R. 2014), individualism and self-enhancement (Wien, A. H., \& Olsen, S. O. (2014), service quality and corporate image (Sanjaya, D. P. W., \& Yasa, N. N. (2018).

Also, many researchers have studied the relationship between Word of Mouth (WOM) and credence attributes (Chung et.al 2011), brand love (Yasin et. al 2013). Komarraju, M., Karau, S. J., Schmeck, R. R., \& Avdic, A. (2011) studied how learning styles can build the relationship between personality traits and academic achievement. 
However, besides, the impact of various moderators like the valence of WOM (Olsen et. al 2014), emotions like anger and excitement (Voyer, P., \& Ranaweera, C. 2015), awareness and complexity of the decision needs to be explored (Martensen, A., \& Gronholdt, L. 2016). An investigation of how Word of Mouth (WOM) interact with brand name affecting consumer's perception (Chung et. al 2011) and why some Word of Mouth (WOM) communications do not influence at all, whether positive or negative (Casielles et. al 2013) is important in the context of examining the effects of Word of Mouth (WOM) on consumers. Kundu, S., \& Rajan, C. R. (2016) argued that there is a need to study the impact of Word of Mouth (WOM) on various personality traits and how it affects their purchase intention. There is a lack of connection in the relationship between personality type and consumer buying decisions (Musa, M., Haeruddin, M. I. W., \& Haeruddin, M. 2018).

Traditionally, word of mouth marketing is the spread of information from one person to another based on recommendations. Word of Mouth (WOM) can be positive or negative. Positive WOM comes when there is a strong trust relationship with the customers which leads to purchase intentions (Yasin, M., \& Shamim, A. 2013). Negative word-of-mouth includes negative opinions that emphasize customers' dissatisfaction with the product or service. Respondents offer negative WOM on brands they are likely to choose (East et.al 2009). Further, Word of Mouth (WOM) can be shared through online or offline sources. Offline WOM is very influential because both receiver and sender are aware of each other. Quality, authority, authenticity, and interestingness are important factors for the sender while giving information to the receiver (Huang, M., Cai, F., Tsang, A. S., \& Zhou, N. 2011). Online WOM, also known as electronic WOM, is spread by customers via the internet. It occurs when the sender's identity is not known.

In this study, we seek to answer the following research questions: What kind of personality traits of influencers is important for those who generate positive Word of Mouth (WOM)? How do emotions help in generating positive Word of Mouth (WOM) is generated? How positive Word of Mouth affects the consumer buying decision? The objective of this paper is to investigate the role of the Big five personality traits of influencers on positive Word of Mouth and consumer buying decisions. The paper is organized to provide an insight into the literature on Word of Mouth (WOM), Personality traits, the valence of WOM, emotions including anger and excitement, and consumer buying decisions.

Thus, the current research attempts to add to the existing literature on consumer buying decisions by investigating the effect of positive WOM as well as the moderating role of emotions including excitement and anger in the consumer buying decisions. Openness to new experiences and extraversion traits influences the buying ability of the consumer. Excitement moderates the relationship between the big five personality traits and consumer buying decisions. 


\section{Literature Review}

\subsection{Theoretical basis: Big Five personality traits theory}

The Big Five personality traits theory is based on the assumption about what people are and what a theory of personality should be. It is a scientific study of the personality of individuals and groups. This theory helps to better understand the personality of an individual. Under this theory, there is no role of personal experience of the theorists. This theory has been applied widely and consists of five factors: Openness to new experiences, conscientiousness, extraversion, agreeableness, and neuroticism. Lin, L. Y. (2010) conducted a study to explore the relationship between consumer personality traits, brand personality, and brand loyalty. The findings suggest a significantly positive relationship between agreeableness and excitement brand personality, sincerity brand personality, and competence brand personality. It also suggests agreeableness and openness both have a significant influence on affective loyalty and action loyalty. The study of personality has considered a high level of conscientiousness, agreeableness, extraversion as a protective factor and a high level of neuroticism as a risk factor.

The research goal of this study is to determine the relationship between the personality traits of influencers and their motivation to deliver Word of Mouth (WOM). The Big Five personality traits have been used in several studies as predictors for the consumers' purchase behavior. The five-factor model (FFM), also known as the 'Big Five personality traits is used in the study of research and personality. Psychologist Lewis Goldberg considered OCEAN (Openness, Conscientiousness, Extraversion, Agreeableness, Neuroticism) as the 'Big Five' factors of personality.

\section{Influencers:}

According to Gupta 2001 (p.3), "Influencer is a person who influences the purchase decision intentionally or unintentionally". Influencers are considered hand-raisers as they engage with different brands and volunteer for different marketing programs. Influencers are consumers who seek out information and share their views, recommendations with other people (Keller and Fay, 2016). Social media influencers are identified in the advertising field to expand coverage of any business organization (Lim et.al, 2017). Baramidze (2018) defined Influencer marketing as targeting a specific audience and influence their views. It is a mix of content marketing and social media marketing where the content is created not by the brand itself but by the influencers who provide information in social media. The customers' attention has shifted from traditional advertisements to online influencers.

H1: Big five personality traits of influencers are associated with Positive Word of Mouth (WOM).

\subsubsection{Openness:}

The openness to a new experience is characterized by a willingness to try new things. It is the extent to which people are open to new ideas. This dimension describes someone intellectually curious, imaginative, creative, and adventurous. They have active imaginations and a wide variety of interests. Openness has a significant positive relationship with brand evangelism 
(Doss, S. K., \& Carstens, D. S. 2014). When there is a high level of openness, consumers will spend more money on buying decisions (Musa et.al 2018). Individuals who are loyal to a particular brand are more like to share their opinions in the form of Word of Mouth (WOM). So, it can be hypothesized that:

H1(a): Influencers with a high level of Openness to new experiences are likely to share Positive Word of Mouth (WOM) with others.

\subsubsection{Conscientiousness:}

Conscientiousness is defined by the organized, planned, and achievement-oriented behavior of individuals (Patel, P. C., \& Thatcher, S. M. (2014). It enables a person to be aware of their actions. This dimension includes high levels of motivation, telling the truth, and sharing real experiences with others. So, it can be hypothesized that:

H1(b): Influencers with a low level of conscientiousness are likely to share Positive Word of Mouth (WOM) with others.

\subsubsection{Extraversion:}

Extraversion is an important factor in consumer behavior for sharing Word of Mouth. It is considered by associating with new people. Furthermore, Extraversion is associated with brand evangelism (Doss et. al 2014). The higher an individual score on extraversion, the more an individual is outgoing, socially confident, and talkative (Avdic et. al 2011) person. They feel positive emotions and are mostly optimistic. They tend to share Word of Mouth when socially interacting (Thatcher et. al 2012) and it is reasonable to assume that these individuals exchange opinions about products and services. So, it can be hypothesized that:

H1(c): Influencers with a high level of Extraversion are likely to share Positive Word of Mouth (WOM) with others.

\subsubsection{Agreeableness:}

This dimension describes a personality dimension that assesses one's attitudes and behavior towards others. It comprises trust, kindness, and affection towards others (Husnain, M., Qureshi, I., Fatima, T., \& Akhtar, W. 2016). Agreeable people are characterized as selfless, cooperative, and modest. Agreeableness is highly associated with excitement, sincerity, competence brand personality, and affective loyalty (Lin, L. Y. 2010). So, it can be hypothesized that:

H1(d): Influencers with a high level of Agreeableness are likely to share Positive Word of Mouth (WOM) with others.

\subsubsection{Neuroticism:}

Neuroticism refers to the degree of emotional stability and anxiety (Avdic et. al 2011). This dimension ranges from emotional stability to emotional instability. Neuroticism is positively related to brand evangelism (Doss et. al 2014). Neuroticism is associated with behavior that is related to the degree to experience anxiety and stress (Akhtar et. al 2016). The study of personality has observed that a high level of neuroticism act as a risk factor (Sarah et.al 2018). So, it can be hypothesized that: 
H1(e): Influencers with a low level of Neuroticism are likely to share Positive Word of Mouth (WOM) with others.

\subsection{Emotions:}

Schutz et al. (2011) pointed out two key aspects of the definition of emotion. First, emotions involve judgments and appraisals of what has happened during a particular person-environment transaction. Individuals assess where they are about where they want to be about their own goals, values, and beliefs as well as their social network. Second, emotions are social constructs that arise from social-historical contexts. Emotions arise when something happens to an important individual (Gross, J. J. 2002). Lopes, P. N., Salovey, P., Cote, S., Beers, M., \& Petty, R. E. (2005) examined the relationship between emotional regulation abilities and the quality of social relationships. Emotion has played a very important role in human relationships as well as the motivational force indicating that what is best and worst in human behavior (Mira et.al 2014). Emotion regulation refers to the processes by which individuals influence which emotions they have, when they have them, and how they experience or express them (Gross, J. J. 2002). It is important to consider both emotional abilities and dispositions to understand social interaction. Individuals which are high on emotional regulation abilities are more sensitive (Lopes et.al 2005).

In this study, the main focus is on excitement and anger. Excitement is considered a fundamental dimension that captures the majority of variance in personality ratings for brands across individuals and product categories. Excitement relates to the extent to which the brand makes consumers feel that they are energized and are experiencing something special (Aaker, J. L. 1997). Mira et.al (2014) examined the impact of excitement on brand personality leading consumers to buy those brands. Emotion regulation aims to enhance the experience of positive emotions and reduce the experience of negative emotions (Gross, J. J. 2002). Consumers who reported an experience involving anger or frustration were more likely to engage in negative Word of Mouth (WOM) for taking revenge in normal emotional conditions (Wetzer, I. M., Zeelenberg, M., \& Pieters, R. 2007). According to Soric, I., Penezic, Z., \& Buric, I. (2013), male and older students, less emotionally stable and with low learning value are more prone to higher levels of negative emotions of anger and unhappiness. Offline WOM includes an emotional dimension that is concerned with the sharing of emotions whether positive or negative. It involves one-to-one conversations which are personal and interactive. (Lovett et al. 2013, Eisingerich et. al 2015). People might seek feedback while sharing Word of Mouth (WOM). Emotional commitment, also known as affective commitment, is the customer's emotional attachment to the brand (Elyria Kemp and My Bui, 2011). WOM is more influential when it comes to offline sources than online sources (Lopez et. al 2011). WOM is a traditional source of sharing information and experience. It occurs when both the sender and receiver have a strong relationship and trust. Offline sources have a significant impact than online sources on WOM. Consumers are less likely to provide WOM on online sources than offline sources because of the risk associated with online sources (Eisingerich et. al 2015). Openness has a significant positive relationship with the loyalty of brands (Lin, L. Y. 2010). Extraversion and agreeableness are positively associated with excitement brand personality (Lin, L. Y. 2010). 
Openness, neuroticism, and agreeableness are indirectly related to violent behavior through aggressive attitudes (Barlett, C. P., \& Anderson, C. A. 2012). So, it can be hypothesized that: $\mathrm{H}$ 2: Big five personality traits of influencers have a significant influence on the emotions of consumers.

$\mathrm{H} 2$ (a): Big five personality traits of influencers are positively influenced by the excitement level of an individual.

$\mathrm{H} 2$ (b): Big five personality traits of influencers are negatively influenced by the anger level of an individual.

\subsection{Word of Mouth (WOM)}

Word of Mouth (WOM) also known as a consumer-to-consumer interaction has gained importance in this decade. It is informal communication between different consumers regarding a particular product or service (Shi, W., Tang, L., Zhang, X., Gao, Y., \& Zhu, Y. 2016). WOM is a social process that influences the behavior and attitude towards a product or service (Hamilton, R., Vohs, K. D., \& McGill, A. L. (2014), Batra, R., \& Keller, K. L. (2016). WOM is a conversation of consumers about the experiences faced with a product or service. It is a part of the digital customer experience (Stephen, A. T. 2016). Brand experiences vary in terms of strength and intensity (Yasin et.al 2013). Most consumers tend to purchase products with well-known brands. Word of Mouth (WOM) receivers with little experience or knowledge about a particular product is likely to lack confidence regarding an appropriate decision. WOM is not only concerned about information on products or services but also the experience of the consumers (Chung et. al 2009, Mikalef, P., Pappas, I. O., \& Giannakos, M. N. (2017). There exists a link between experience and risk relating to a particular purchase decision (Casielles et. al 2013). Satisfaction, high social risk, unsolicited WOM are the determinants of WOM (Olsen et al. 2014). Brand image has a direct relationship with the word of mouth of customers. Brand messages have to be stronger to generate word of mouth (Anggraeni, A. 2015). Consumers are more likely to give WOM when they love the brand (Batra et.al 2016).

Word of mouth is the method of advertisement without expenditure and it has a considerable impact on consumers (Mira, A., Leylan, L., Panahandeh, A., Abbaslu, I., \& Iran, S. 2014). Highly individualistic consumers are motivated to provide WOM by self-enhancement (Lovett, M. J., Peres, R., \& Shachar, R. (2013), Berger, J. (2014), Olsen et al. (2014), Eisingerich, A. B., Chun, H. H., Liu, Y., Jia, H., \& Bell, S. J. (2015), Huang et. al (2016). Word of Mouth (WOM) is interpersonal communication and serves the following key functions (Berger2013 et. al): a) Self-Presentation- It refers to how people present themselves to the outside audience while sharing the Word of Mouth (WOM), Emotion Regulation- It refers to how people manage their emotions while social interaction b) Information Acquisition- It refers to the sharing of information for resolving the issues of others c) Social Bonding- It refers to how people develop bonds while socially interacting d) Persuading others- It refers to the ability of consumers sharing Word of Mouth (WOM) and persuading others to buy a particular product.

The basic idea behind WOM is that information about products, services, stores, and companies can spread from one consumer to another (Ennew et.al 2000). Forgiving WOM, consumers evaluate the likeability and credibility of the product or service. Customer satisfaction has an 
important influence on spreading WOM and it is generally given by trustworthy and credence customers as the customer share their experience with others (Chung et. al 2009). Politeness is encouraged when sharing opinions with others (Hamilton, R., Vohs, K. D., \& McGill, A. L. 2014). WOM content includes volume and quality which influences the purchase decision. Consumers will collect information about the product while discussing it with social groups and they will observe the behavior of those who share their experiences related to purchasing decisions (Wang, Y., \& Yu, C. 2017). WOM is an important tool for consumers (Jalilvand et. al 2016) which influences consumer decision-making (Brown et. al 2017). There is a linkage between WOM and purchase intention which is mediated by trust. Trust is an important factor which in turn, consumer decision-making. Marketers focus on building trust among customers by interacting and receiving feedback from customers in the form of WOM. WOM has received a huge amount of attention in marketing (Kim et. al 2017). Before the launch of new products, most marketers try to generate Word of Mouth (WOM) for the product on social networking sites. Viral marketing is creating Word of Mouth (WOM) and leading to social status within the customers (Musa et. al 2018).

\subsection{Consumer buying decision}

Word of Mouth (WOM) can significantly influence the consumer's buying decisions. WOM influences others' views and thoughts. The decision process includes evaluating, acquiring, consuming, and ordering goods and services (Ahmad, N., Vveinhardt, J., \& Ahmed, R. 2014). The role of consumers is increasing as now they search for information about products, purchase, consume, and then share their reviews or experiences in the form of Word of Mouth (Stephen 2016). Consumers should share their opinion about any products. The majority of consumers tend to rely on WOM for buying daily and long-term consumption goods. $76 \%$ of the consumer buying decisions result from WOM (Jalilvand et. al 2016).

The literature of WOM has recognized WOM as a key influencer in consumer decision-making (Nguyen and Romaniuk, 2014). Consumers might go through different feelings when involved in consumer buying decisions. This includes before, during, and after purchase decisions. Today consumers interact with each other through multiple sources in more nonlinear and circular ways. Consumers follow a sequence of steps when making a purchase decision (Batra et.al 2016). Every stage in the consumer buying decision puts the consumer in the information processing stage. Both online and offline sources interact with each other in the consumer buying decision process. (Stephen 2016).

A high level of purchase intention arises from those people who receive more positive than negative Word of Mouth (Magnus Soderlund, Sara Rosengren 2007). Positive WOM has more impact than negative WOM in the case of buying decisions (East et. al 2008, Casielles et. al 2013). Word-of-mouth is usually spread because the sender of the message wishes to share their positive and negative experiences to help others in decision-making processes or to decrease his or her doubts regarding their behaviors (De Valck, K., Van Bruggen, G. H., \& Wierenga, B. 2009). Positive WOM increases usage intentions than negative WOM (Berger et. al 2014). So, it can be hypothesized that: 
H3: Positive Word of Mouth (WOM) has a significant influence on the consumer buying decision.

Consumers with pleasure and arousal lead to a consumer buying decision. Arousal is the extent to which one feels excited and stimulated. There is a strong relationship between consumer buying decisions and emotions (Lee, G. Y., \& Yi, Y. 2008). So, it can be hypothesized that: H4: Individual emotions have a significant influence on consumer buying decisions. H4(a): The excitement level of an individual has a positive influence on Consumer buying decisions.

H4(b): The anger level of an individual has a negative influence on Consumer buying decisions.

\subsection{Valence of Word of Mouth (WOM) - Positive and Negative Word of Mouth (WOM)}

Positive word-of-mouth involves positive feedback from customers who are satisfied with the experience they have had with a product or service. The positive WOM achieved will strengthen the corporate image. The marketers should conduct market research to increase the ability of customers to share positive WOM (Casielles et. al 2013, Kim et. al 2017). Positive WOM can increase customer attitudes and thus, control their switching behaviors (Berger et. al 2014). Self-enhancement is a factor that affects positive WOM (Eisingerich et. al 2015). The positive valence of WOM has a strong impact on consumers' purchase intentions (Wang et. al 2015). Brand love can lead to positive word of mouth (Anggraeni, A. 2015). Consumers who engage in positive WOM become the brand advocates of it (Batra et.al 2016). Good quality service leads to high satisfaction among patients and this will lead to patients providing positive WOM (Sanjaya et al. 2017). Nowadays, marketers consider positive WOM as the oldest form of communication as it comes from experts or social acquaintances. The expertise of the WOM giver influences the competency of the receiver (Huang et. al 2016). It affects the brand image and identity. The better quality of services will lead to a higher level of satisfaction. (Sanjaya et.al 2018). Positive WOM is concerned with product recommendations.

Negative WOM is concerned with complaining behavior. Negative WOM harms the evaluation of search attributes than credence attributes. Negative information has a great influence than positive information on decision-makers (Chung et al. 2011). The companies should connect with customers on social media to mitigate the effects of negative WOM (Casielles et. al 2013). The negative valence of WOM hurts purchase intentions (Wang et. al 2015).

Valence-specific factors will show the effectiveness of Word of Mouth (Kim et. al 2017). Word of Mouth (WOM) is positively linked to positive emotions and negatively linked to negative emotions of the receiver. Positive or negative WOM enhances the ability of the receiver to feel positive or negative about certain advice offered by the sender (East et. al 2008) and they also differ when the brands are similar to each other (Casielles et. al 2013). Consumer acceptance towards negative WOM is higher than positive WOM as people are willing to believe negative information quickly (Huang et. al 2011). Word of Mouth (WOM) influence increases with the increase in involvement. The increase in excitement level in the case of brands will lead to a consumer making the more positive word of mouth. Excitement can affect consumers for performing word of mouth by changing their mental image (Mira et.al 2014). Excitement has a direct relationship with online fashion brand image. The excitement dimension of brand 
personality has a positive impact on word-of-mouth (Anggraeni, A. 2015). Various emotions like anger or excitement as moderators on Word of Mouth (WOM) have to be studied (Voyer and Ranaweera,2015). Positive WOM can create higher expectations than negative WOM and it results in a low level of satisfaction. Consumers' expectations are positively influenced by WOM. WOM hurts consumer satisfaction, which is moderated by product type (Shi W et al. 2016).

So, it can be hypothesized that:

H5: Emotions have a significant influence on Positive WOM.

H5a): Excitement level has a significant influence on Positive WOM.

H5(b): Anger level has a negative influence on Positive WOM.

\subsection{Conceptual Framework}

Figure 1 shows the conceptual framework of the relationships between the Big five personality traits, Emotions, Positive Word of Mouth, and consumer buying decisions.

\section{Figure1: Conceptual framework}

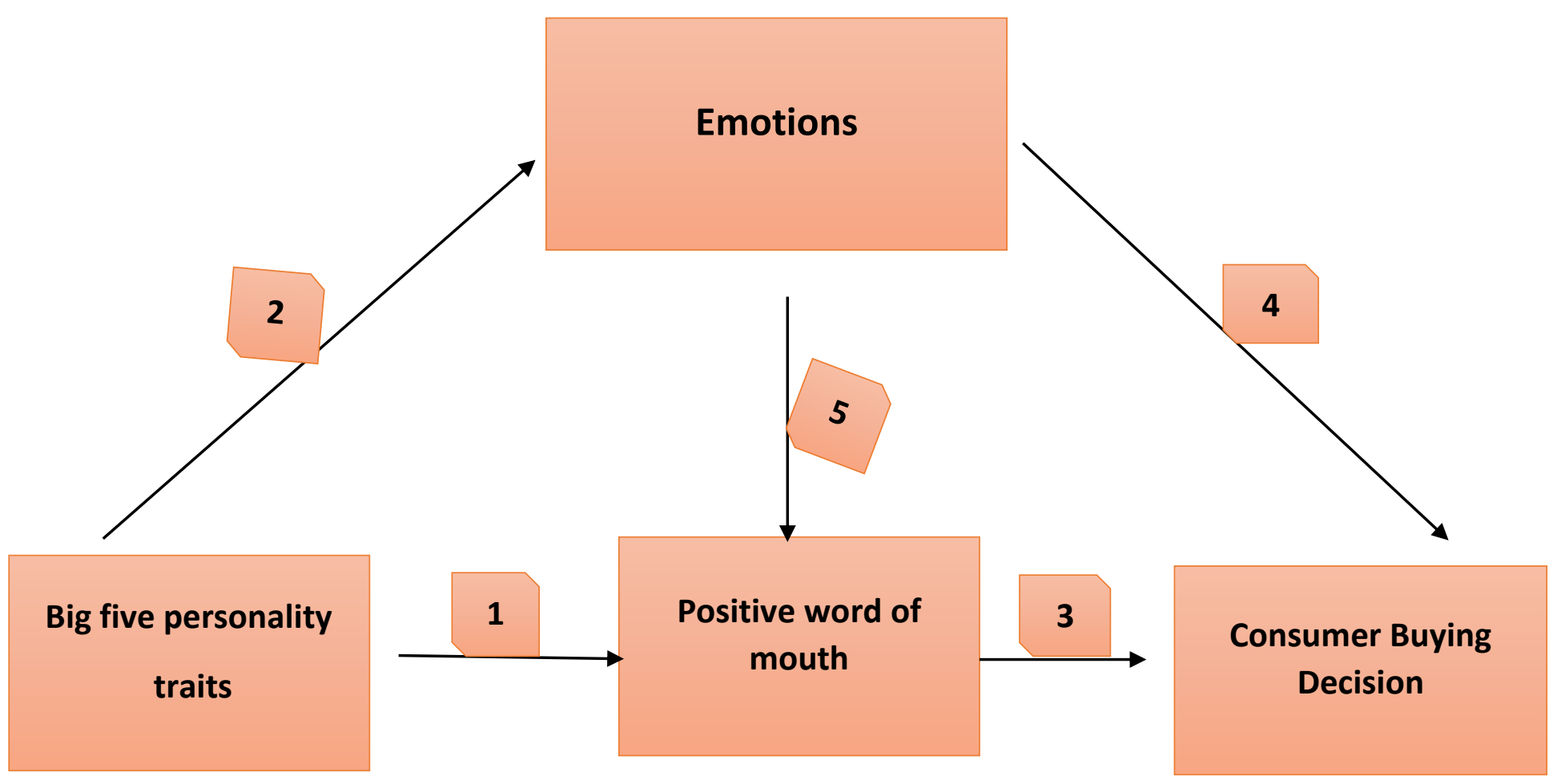

\section{Research Methodology}

\subsection{Plan of analysis:}

To test the research hypotheses of this study, a quantitative method with statistical analysis has been conducted to understand the effect of Big five personality traits of influencers. This study examines the effect of the Big five personality traits of influencers on Positive Word of Mouth and Consumer Buying Decisions. Big five personality traits have been divided into five categories: Openness to new experiences, Conscientiousness, Extraversion, Agreeableness, 
and Neuroticism. Statistical analysis, such as correlation and regression through SPSS Statistics, have been used to obtain the relationship between variables. Under this study, emotions are treated as moderating variable which includes anger and excitement.

\subsection{Instrument design:}

In this study, borrowed scale questionnaires are used. The scales for constructs have been taken from previously validated scales. The items for various constructs have been obtained from various sources. In this study, close-ended questions are used. The screening question includes only 1 item which focuses on purchase probability. This item is derived from Casillas, R.V., Alvarez, L.S., \& Lanza, A.D. (2013). The items of main questions are Big five personality traits, consumer buying decisions, Positive Word of Mouth, and emotions. Openness comprises of 4 items and Extraversion comprises of 7 items has been adopted from Bogdan Anastasiei and Nicoleta Dospinescu. Neuroticism comprises of 3 items, Agreeableness comprises of 5 items and Conscientiousness comprises of 3 items. These three are derived from McBride, N. L. (2001). Positive Word of mouth comprises 3 items, which have been obtained from Tuškej, U., Golob, U., \& Podnar, K. (2013). Emotions include anger and excitement. The items of anger have and excitement is derived from McBride, N. L. (2001). The items of Consumer buying decisions have been derived from Jiang, Z., \& Benbasat, I. (2007). Consumer buying decisions are comprised of 4 items. The questionnaire includes 1 screening question,36 main questions, and 6 identification questions.

One of the most commonly used interval scale questions, the question is arranged in a 5point Likert Scale question where each emotion is denoted with a number and the variables range from extremely dissatisfied to extremely satisfied. Under this study, a five-response category scale ranging from "strongly disagree" to "strongly agree" is used. The respondents are presented with questionnaires containing a set of statements to rate their attitude towards the objects. For example, the respondents might be asked to rate their experience $(1=$ strongly disagree, $2=$ disagree, $3=$ neither agree nor disagree, $4=$ agree, $5=$ strongly agree) to the series of statements.

Under this study, a screening question was asked from the respondents. Out of $300,77 \%$ of respondents prefer to buy a product only after receiving a recommendation and $23 \%$ prefer to buy the product before receiving a recommendation.

\subsection{Sampling:}

Each respondent was selected based on a convenience sampling approach. Convenience sampling is a type of non-probability sampling technique. Non-probability sampling focuses on sampling techniques that are based on the judgment of the researchers. It is a more quick and economical way. Respondents filled the online questionnaire between November 2020 to October 2021. The data were collected through online questionnaires which were circulated through Google forms on various social networking sites to a sample of 500 respondents. Out of 500 responses, 300 were valid which were further used for analysis. The object of measurement/unit of analysis is individual consumers. Structured questionnaires are used in 
this study to collect quantitative data. The questionnaire is planned and designed to gather precise information.

\section{Data Analysis:}

\subsection{Demographic Analysis:}

Based on analyses of the respondents' profiles, the majority of participants were females which represent $70 \%$ while males represented only $30 \%$ of the sample size. The study found that the majority of the respondents fall in the range of 18 to 24 and 25 to 34 years Out of the sample, $54 \%$ were between the ages of 18 and 24, 35\% were between 25 and 34, 5\% between 35 and 44, $5 \%$ between 45 and 54, and $1 \%$ above 54 . The respondents were classified into seven categories of employment status. Among the respondents, $51 \%$ are full-time employed, $6 \%$ part-time employed, $1 \%$ unemployed, $16 \%$ self-employed, $2 \%$ homemaker, $23 \%$ students and $1 \%$ retired.

\subsection{Results, findings, and interpretation of findings: \\ 4.2.1 Proposed testing of reliability and validity}

The reliability of the questionnaire that was used for the data collection is used properly to understand the opinions of participants. The reliability statistics for social sciences (SPSS) are used with the help of Cronbach Alpha. Cronbach's alpha is a measure used to assess the reliability, or internal consistency, of a set of scale or test items. This study adopted Cronbach's alpha value as a tool for reliability. The scale used in this study is adapted and hence, there will be reliability testing only. Validity testing is not done in the case of adapted questions. It is necessary to make sure not to mix positive or negative recorded questions, it will result in negative alpha. Higher Cronbach's alpha value, the higher the internal consistency is. If a value is higher than 0.70 , then it showed that the reliability of measurement is high. Reliability should be greater than 0.70 . After analyzing the data, the average reliability coefficient (Cronbach's Alpha) for all parts of the survey was found to be 0.836 , which exceeded the recommended level of 0.70 .

The factor analysis was conducted to understand the different factors that were framing the main questions of the research. The Kaiser-Meyer-Olkin Measure of Sampling Adequacy should be above 0.60 and, in this case, it is .670 . The sample size is adequate according to this information.

\subsubsection{Correlation Analysis}

Correlation analysis is used to quantify the degree to which two variables are related. Through the correlation analysis, the correlation coefficient is calculated which tells how much one variable changes when the other one does. It provides a linear relationship between two variables. For this study, Pearson correlation has been used. 
Table 1:

\begin{tabular}{|l|l|l|l|l|l|l|l|l|l|}
\hline & $\mathbf{O}$ & $\mathbf{C}$ & $\mathbf{E}$ & $\mathbf{A}$ & $\mathbf{N}$ & $\mathbf{A n g e r}$ & $\mathbf{E x c i t e m e n t}$ & $\mathbf{P W O M}$ & $\mathbf{C B D}$ \\
\hline $\mathbf{O}$ & 1 & $.208^{*}$ & $.231^{*}$ & .102 & .035 & $.369^{* *}$ & $.388^{* *}$ & $.442^{* *}$ & $.382^{* *}$ \\
\hline $\mathbf{C}$ & $.208^{*}$ & 1 & $.336^{* *}$ & .180 & .082 & .120 & .150 & .163 & .105 \\
\hline $\mathbf{E}$ & $.231^{*}$ & $.336^{* *}$ & 1 & .163 & $.272^{* *}$ & $.314^{* *}$ & $.466^{* *}$ & $.290^{* *}$ & $.203^{*}$ \\
\hline $\mathbf{A}$ & .102 & .180 & .163 & 1 & -.043 & .164 & $.223^{*}$ & .094 & $.261^{* *}$ \\
\hline $\mathbf{N}$ & .035 & .082 & $.272^{* *}$ & -.043 & 1 & -.109 & .020 & -.065 & -.016 \\
\hline $\mathbf{A n g e r}$ & $.369^{* *}$ & .120 & $.314^{* *}$ & .164 & -.109 & 1 & $.346^{* *}$ & $.498^{* *}$ & $.377^{* *}$ \\
\hline $\mathbf{E x c i t e m e n t}$ & $.388^{* *}$ & .150 & $.466^{* *}$ & $.223^{*}$ & .020 & $.346^{* *}$ & 1 & $.346^{* *}$ & $.420^{* *}$ \\
\hline PWOM & $.442^{* *}$ & .163 & $.290^{* *}$ & .094 & -.065 & $.498^{* *}$ & $.346^{* *}$ & 1 & $.493^{* *}$ \\
\hline CBD & $.382^{* *}$ & .105 & $.203^{*}$ & $.261^{* *}$ & -.016 & $.377^{* *}$ & $.420^{* *}$ & $.493 * *$ & 1 \\
\hline
\end{tabular}

*. Correlation is significant at the 0.05 level (2-tailed).

**. Correlation is significant at the 0.01 level (2-tailed).

Analysis of Table 1 shows that Agreeableness, Excitement, Positive word of mouth, and Consumer buying decision are negatively correlated with Neuroticism at $\mathrm{P}<0.05$ level, while all other variables are positively correlated with each other. Personality traits including openness to new experiences, extraversion are significantly correlated while neuroticism is negatively correlated with Positive WOM. Personality traits, Positive WOM, and consumer buying decisions have a significant correlation with emotions but excitement is highly correlated than anger.

\subsubsection{Regression Analysis}

Regression analysis describes how the changes in each independent variable are related to changes dependent variable. Under this study, there is mediating role of Positive WOM in the relationship of big five personality traits and consumer buying decisions. For the purpose of understanding the relationship between independent and dependent variables, linear regression analysis has been done. Multicollinearity in regression analysis refers to showing strongly interrelated independent variables in the model are. VIFs are checked for multicollinearity problems. As a rule of thumb, VIF above 5.0 suggests problems. None are indicated here.

The regression analysis has been done between Personality traits of influencers as the independent variable and Positive WOM as the dependent variable. The result indicates that model F has a significant value and the Personality traits had a significant effect $(\rho=0.02<0.05)$ on buying decision $(\beta=0.308)$. The significance value is below $5 \%$ which shows that the model 
is a good fit for explaining the relationship that is present between the variables. The $\beta$ value of $\mathrm{H} 1$ shows that one unit increase in personality traits brings a $30.8 \%$ increase in positive WOM. The result provided sufficient evidence to support H1. The R square value of this model is (.095) which means that $9.5 \%$ variation in Positive WOM is caused by the independent variable.

The $\mathrm{T}$ value associated with the independent variable is also significant. The estimated regression line is:

Positive WOM = .605 + 1.659 (Big five personality traits)

Openness to new experiences shows a significant relationship $(\rho=0.000<0.05)$ with Positive WOM. The $\beta$ value (0.442) of H1a shows that a one-unit increase in openness to new experiences brings a $44.2 \%$ increase in positive WOM. The result provided sufficient evidence to support H1a. The R square value of this model is (.195) which means that the independent variable has explained $19.5 \%$ variance in positive WOM. Conscientiousness has no significant relationship with Positive WOM. The results are not sufficient to support H1b. Extraversion shows a significant relationship $(\rho=0.000<0.05)$ with Positive WOM. The $\beta$ value $(0.290)$ of H1c shows that one unit increase in extraversion brings a $29 \%$ increase in positive WOM. The result provided sufficient evidence to support H1c. The R square value of this model is (.084) which means that the independent variable has explained $8.4 \%$ variance in positive WOM. Agreeableness and neuroticism have no significant relationship with Positive WOM. The results are not sufficient to support H1d and H1e.

The regression analysis has been done between Personality traits as independent variables and Emotions as the dependent variable. The result indicates that the Personality traits had a significant effect $(\rho=.000<0.05)$ on emotions $(\beta=0.421)$. The $\beta$ value of $\mathrm{H} 2$ shows that one unit increase in personality traits brings a $42.1 \%$ increase in emotions. The result provided sufficient evidence to support H2. The R square value of this model is (.177) which means that the independent variable has explained a $17.7 \%$ variance in emotions. The estimated regression line is:

Emotions $=.709+1.128$ (Big five personality traits)

Big five personality traits show a significant relationship $(\rho=0.000<0.05)$ with the excitement level of an individual. The $\beta$ value $(0.820)$ of $\mathrm{H} 2$ a shows that one unit increase in the big five personality traits brings an $82 \%$ increase in the excitement level of an individual. The result provided sufficient evidence to support $\mathrm{H} 2 \mathrm{a}$. The $\mathrm{R}$ square value of this model is (.673) which means that the independent variable has explained $67.3 \%$ variance in excitement level. The big five personality traits have no significant relationship with the anger level of an individual. The $\beta$ value (0.279) of $\mathrm{H} 2 \mathrm{~b}$ shows that one unit increase in the big five personality traits brings a $27.9 \%$ decrease in the anger level of an individual. The results are not sufficient to support $\mathrm{H} 2 \mathrm{~b}$.

The regression analysis has been done between Positive WOM as the independent variable and Consumer buying decision as to the dependent variable. The result indicates that the Positive WOM had a significant effect $(\rho<0.05)$ on Consumer buying decisions $(\beta=0.493)$. The $\beta$ value of $\mathrm{H} 3$ shows that one unit increase in positive WOM brings a $49.3 \%$ increase in consumer 
buying decisions. The result provided sufficient evidence to support $\mathrm{H} 3$. The $\mathrm{R}$ square value of this model is (.243) which means that the independent variable has explained a $24.3 \%$ variance in consumer buying decisions. The estimated regression line is:

Consumer buying decision $=.509+1.488$ (Positive WOM)

The regression analysis has been done between Emotions as the independent variable and Consumer buying decisions as to the dependent variable. The result indicates that the emotions had a significant effect $(\rho=.000<0.05)$ on Consumer buying decisions $(\beta=0.486)$. The $\beta$ value of $\mathrm{H} 4$ shows that one unit increase in emotions brings a $48.6 \%$ increase in the consumer buying decision. The result provided sufficient evidence to support H4. The R square value of this model is (.236) which means that the independent variable has explained a $23.6 \%$ variance in consumer buying decisions. The estimated regression line is:

Consumer buying decision $=.584+1.266$ (Emotions)

The excitement level of an individual shows significant relationship $(\rho=0.000<0.05)$ with Consumer buying decisions. The $\beta$ value $(0.420)$ of $\mathrm{H} 4 \mathrm{a}$ shows that one unit increase in the excitement level of an individual brings a $42 \%$ increase in the consumer buying decision. The result provided sufficient evidence to support $\mathrm{H} 4 \mathrm{a}$. The $\mathrm{R}$ square value of this model is (.176) which means that the independent variable has explained a $17.6 \%$ variance in consumer buying decisions. According to hypothesis $\mathrm{H} 4 \mathrm{~b}$, the anger level of an individual has a negative influence on consumer buying decisions but the results show a significant relationship $(\rho=0.000<0.05)$. The results are not sufficient to support H4b.

The regression analysis has been done between Emotions as the independent variable and Positive WOM as the dependent variable. The result indicates that the Emotions had a significant effect $(\rho=.000<0.05)$ on Positive WOM $(\beta=0.515)$. The $\beta$ value of H5 shows that one unit increase in emotions brings a $51.5 \%$ increase in positive WOM. The result provided sufficient evidence to support H5. The R square value of this model is (.265) which means that the independent variable has explained $26.5 \%$ variance in Positive WOM. The estimated regression line is:

Positive $\mathrm{WOM}=.442+2.085$ (Emotions)

Excitement level shows a significant relationship with Positive WOM. The $\beta$ value (0.346) of $\mathrm{H} 4 \mathrm{a}$ shows that one unit increase in excitement level brings a $34.6 \%$ increase in Positive WOM. The result provided sufficient evidence to support H5a. The R square value of this model is (.120) which means that the independent variable has explained $12 \%$ variance in Positive WOM. Anger level has a positive relationship with positive WOM. Under this study, it is hypothesized that anger has a negative influence on positive WOM. The result is not sufficient to support H5b.

\section{Summary of results:}

\begin{tabular}{|l|l|}
\hline Hypothesis & Findings \\
\hline H1 & Accepted \\
\hline H1 (a) & Accepted \\
\hline H2 (b) & Rejected \\
\hline H3 (c) & Accepted \\
\hline
\end{tabular}




\begin{tabular}{|l|l|}
\hline H4 (d) & Rejected \\
\hline H5 (e) & Rejected \\
\hline H2 & Accepted \\
\hline H2 (a) & Accepted \\
\hline H2 (b) & Rejected \\
\hline H3 & Accepted \\
\hline H4 & Accepted \\
\hline H4 (a) & Accepted \\
\hline H4 (b) & Rejected \\
\hline H5 & Accepted \\
\hline H5 (a) & Accepted \\
\hline H5 (b) & Rejected \\
\hline
\end{tabular}

\subsection{Implications:}

This study holds important implications for consumer research and can be assessed from both a theoretical and a practical perspective. Most importantly, this study provides a framework that captures the multiple dimensions and interrelationships between the factors important to a consumer buying decision. Several studies have attempted to explore different aspects of consumer buying decisions, but there has been no study that studied the effect of only one dimension of word of mouth, i.e., positive or negative. Besides, no study has investigated the relationship between emotions and consumer buying decisions. Although there might be some other important factors or determinants on the consumer buying decisions, the present study offers a framework that incorporates the big five personality traits of influencers with it. Therefore, new insights about consumer buying, particularly about the effects of the big five personality traits, emotions, and positive WOM are provided.

The findings reported here provide support for how positive WOM influences the consumer buying decision. The influencers who are open to new experiences and extraverts are most likely to share positive WOM with others. The marketers should try to conduct interactive sessions with these people and make them aware of their products and services. This reduces the expenses of marketing which otherwise a company has to bear. The marketers should build up confidence among these people by conducting various activities and making them feel connected with a particular brand or product. They must understand that satisfied influencers can attract new customers through word of mouth. Companies have to be aware that word of mouth is an important part of the marketing strategy. They must build good relations with the influencers to earn their loyalty, and ensure their commitment. They should know how to use Word of Mouth to improve their marketing strategies and make them efficient and effective. Emotions play an important role in sharing experiences. The person who is excited is likely to share positive WOM and the person who is full of anger is likely to share more negative WOM. The marketers should try to create excitement by suitable designs in their products. Performing effective advertisement by making an exciting image of the brand or product creates awareness and convinces them to make a buying decision and share positive WOM. Customer satisfaction and WOM are important marketing outcomes that affect the profitability of a company. The 
excitement level has a moderating influence on positive WOM leading to consumer buying decisions. The relationship between the big five personality traits and consumer buying decision which is mediated through Positive WOM is found to be significant. Consumers' emotional states may strongly affect individual buying ability.

\subsection{Limitations and directions for Future Research:}

Limitations are important for future researchers to improve the quality of this research or fill the gap of the study. First, data is gathered from a small sample size. Future researches may replicate this study with a larger sample size to enhance generalizability. Second, the time frame for collecting data is very short. Third, the present study only focuses on the effect of the big five personality traits on positive WOM and consumer buying decisions. Future studies may also include other variables which affect word of mouth. Fourth, the data is collected through the medium of an online survey. In this, the non-response rate is very high. In the future, data may be collected through face-to-face interviews. The sampling method used in the current study is convenience sampling. Thus, it is recommended that for the next study, the sampling method would be changed to utilizing probability which is random sampling. Fifth, under this study only the effect of excitement and anger has been studied. In the future, the researchers should study the effect of other emotions on positive WOM.

\section{References}

Aaker, J. L. (1997). Dimensions of brand personality. Journal of marketing research, 34(3), 347-356.

Anggraeni, A. (2015). Effects of brand love, personality, and image on word of mouth; the case of local fashion brands among young consumers. Procedia-Social and Behavioral Sciences, 211, 442-447.

Archer-Brown, C., Kampani, J., Marder, B., Bal, A. S., \& Kietzmann, J. (2017). Conditions in pre-release movie trailers for stimulating positive word of mouth: a conceptual model demonstrates the importance of understanding as a factor for engagement. Journal of Advertising Research, 57(2), 159-172.

Ahmad, N., Vveinhardt, J., \& Ahmed, R. (2014). Impact of word of mouth on the consumer buying decision. European journal of business and management, 6(31).

Anastasiei, B., \& Dospinescu, N. (2018). A model of the relationships between the Big Five personality traits and the motivations to deliver word-of-mouth online. psihologija, 51(2), 215227.

Back, K. J. (2005). The effects of image congruence on customers' brand loyalty in the uppermiddle-class class hotel industry. Journal of Hospitality \& Tourism Research, 29(4), 448-467. Batra, R., \& Keller, K. L. (2016). Integrating marketing communications: New findings, new lessons, and new ideas. Journal of Marketing, 80(6), 122-145.

Barlett, C. P., \& Anderson, C. A. (2012). Direct and indirect relations between the Big 5 personality traits and aggressive and violent behavior. Personality and Individual Differences, 52(8), 870-875.

Berger, J. (2014). Word of mouth and interpersonal communication: A review and directions for future research. Journal of consumer psychology, 24(4), 586-607. 
Casielles, R.V., Alvarez, L.S., \& Lanza, A.D. (2013). The word of mouth dynamic: How positive (and negative) WOM drives purchase probability an analysis of interpersonal and noninterpersonal factors. Journal of Advertising Research, 53(1), 43-60. DOI. 10.2501/JAR53-1-043060

CBC (2010). Creative Brand Com, Word of Mouth Marketing Strategy, online accessed on $26^{\text {th }}$ February 2020 from http://www.creative-brand.com/word-of-mouth/word-of-mouthmarketing-strategy

De Valck, K., Van Bruggen, G. H., \& Wierenga, B. (2009). Virtual communities: A marketing perspective. Decision support systems, 47(3), 185-203.

Doss, S. K., \& Carstens, D. S. (2014). Big five personality traits and brand evangelism. International Journal of Marketing Studies, 6(3), 13.

East, R. (2009). The impact of positive and negative word of mouth on brand choice. ANZMAC 2005 Conference: Advertising/Marketing Communication Issues.

Eisingerich, A. B., Chun, H. H., Liu, Y., Jia, H., \& Bell, S. J. (2015). Why recommend a brand face-to-face but not on Facebook? How word-of-mouth on online social sites differs from traditional word-of-mouth. Journal of Consumer Psychology, 25(1), 120-128.

Ennew, C., Bauerjee, A.K., Li, D. (2000), "Managing word of mouth communication: empirical evidence from India", International Journal of Bank Marketing, Vol. 18, No 2, pp. 75-83.

Gross, J. J. (2002). Emotion regulation: Affective, cognitive, and social consequences. Psychophysiology, 39(3), 281-291.

Hamilton, R., Vohs, K. D., \& McGill, A. L. (2014). We'll be honest, this won't be the best article you'll ever read: The use of dispreferred markers in word-of-mouth communication. Journal of Consumer Research, 41(1), 197-212.

Huang, M., Cai, F., Tsang, A. S., \& Zhou, N. (2011). Making your online voice loud: the critical role of WOM information. European Journal of Marketing.

Husnain, M., Qureshi, I., Fatima, T., \& Akhtar, W. (2016). The impact of electronic word-ofmouth on online impulse buying behavior: The moderating role of Big 5 personality traits. $J$ Account Mark, 5(190), 1-10.

Jiang, Z., \& Benbasat, I. (2007). Research note-investigating the influence of the functional mechanisms of online product presentations. Information Systems Research, 18(4), 454-470.

Le Vigouroux, S., Scola, C., Raes, M. E., Mikolajczak, M., \& Roskam, I. (2017). The big five personality traits and parental burnout: protective and risk factors. Personality and Individual Differences, 119, 216-219.

Lin, L. Y. (2010). The relationship of consumer personality trait, brand personality, and brand loyalty: an empirical study of toys and video games buyers. Journal of Product \& Brand Management.

Lopes, P. N., Salovey, P., Côté, S., Beers, M., \& Petty, R. E. (2005). Emotion regulation abilities and the quality of social interaction. Emotion, 5(1), 113.

Lovett, M. J., Peres, R., \& Shachar, R. (2013). On brands and word of mouth. Journal of marketing research, 50(4), 427-444.

Jalilvand, M. R., Salimipour, S., Elyasi, M., \& Mohammadi, M. (2017). Factors influencing word of mouth behavior in the restaurant industry. Marketing Intelligence \& Planning. 
Komarraju, M., Karau, S. J., Schmeck, R. R., \& Avdic, A. (2011). The Big Five personality traits, learning styles, and academic achievement. Personality and individual differences, 51(4), 472-477.

Kundu, S., \& Rajan, C. R. (2016). Word of mouth: a literature review. Word of Mouth: A Literature Review (Oct 24, 2016).

Lee, G. Y., \& Yi, Y. (2008). The effect of shopping emotions and perceived risk on impulsive buying: the moderating role of buying impulsiveness trait.

Libai, B., Bolton, R., Bugel, M. S., De Ruyter, K., Gotz, O., Risselada, H., \& Stephen, A. T. (2010). Customer-to-customer interactions: broadening the scope of word of mouth research. Journal of service research, 13(3), 267-282.

Lim, B. C., \& Chung, C. M. (2011). The impact of word-of-mouth communication on attribute evaluation. Journal of Business Research, 64(1), 18-23.

Lopez, M., \& Sicilia, M. (2014). Determinants of E-WOM influence: the role of consumers' internet experience. Journal of theoretical and applied electronic commerce research, 9(1), 28-43.

Martensen, A., \& Gronholdt, L. (2016). The effect of word-of-mouth on consumer emotions and choice: findings from a service industry. International Journal of Quality and Service Sciences.

McBride, N. L. (2001). An item response theory analysis of the scales from the international personality item pool and the neo personality inventory-revised (Doctoral dissertation, Virginia Tech).

Meade, A. W., \& Craig, S. B. (2012). Identifying careless responses in survey data. Psychological methods, 17(3), 437.

Mikalef, P., Pappas, I. O., \& Giannakos, M. N. (2017). Value co-creation and purchase intention in social commerce: the enabling role of word-of-mouth and trust.

Mira, A., Leylan, L., Panahandeh, A., Abbaslu, I., \& Iran, S. (2014). The Role of Excitement and Brand Image in Word of Mouth. European Journal of Business and Management, 6(17), 170-177.

Musa, M., Haeruddin, M. I. W., \& Haeruddin, M. (2018). Customers' repurchase decision in the culinary industry: Do the Big-Five personality types matter? Journal of business and retail Management Research, 13(1), 131-137.

Nguyen, C., \& Romaniuk, J. (2014). Pass it on: A framework for classifying the content of word of mouth. Australasian Marketing Journal (AMJ), 22(2), 117-124.

Ozdemira, A., Tozlub, E., Şenc, E., \& Ateşoğlud, H. (2016). Analyses of word-of-mouth communication and its effect on students' university preferences.

Patel, P. C., \& Thatcher, S. M. (2014). Sticking it out: Individual attributes and persistence in self-employment. Journal of Management, 40(7), 1932-1979.

Sanjaya, D. P. W., \& Yasa, N. N. (2018). The Effect of Service Quality on Customer Satisfaction, Positive Word of Mouth, and Corporate Image. IOSR Journal of Business and Management (IOSRJBM), 20(7), 28-33.

Schutz, P.A., Quijada, P.D., de Vries, S., \& Lynde, M. (2011). Emotion in educational context. In S. Järvelä (Ed.), Social and emotional aspects of learning (pp. 64-69). Oxford: Elsevier Shen, W., Huang, J., \& Li, D. (2016). The research of motivation for word-of-mouth: Based on the self-determination theory. Journal of Business and Retail Management Research, 10(2). 
Shi, W., Tang, L., Zhang, X., Gao, Y., \& Zhu, Y. (2016). How does word of mouth affect customer satisfaction? Journal of Business \& Industrial Marketing

Soric, I., Penezic, Z., \& Buric, I. (2013). Big five personality traits, cognitive appraisals, and emotion regulation strategies as predictors of achievement emotions. Psihologijske teme, 22(2), 325-349.

Stephen, A. T. (2016). The role of digital and social media marketing in consumer behavior. Current Opinion in Psychology, 10, 17-21.

Tuškej, U., Golob, U., \& Podnar, K. (2013). The role of consumer-brand identification in building brand relationships. Journal of business research, 66(1), 53-59.

Vazquez-Casielles, R., Suarez-Alvarez, L., \& del Río-Lanza, A. B. (2013). The word of mouth dynamic: How positive (and negative) WOM drives purchase probability: An analysis of interpersonal and non-interpersonal factors. Journal of Advertising Research, 53(1), 43-60.

Voyer, P., \& Ranaweera, C. (2015). The impact of word of mouth on service purchase decisions: Examining risk and the interaction of tie strength and involvement. Journal of Service Theory and Practice, 25(5), 636-656.

Wang, Y., \& Yu, C. (2017). Social interaction-based consumer decision-making model in social commerce: The role of word of mouth and observational learning. International Journal of Information Management, 37(3), 179-189.

Wetzer, I. M., Zeelenberg, M., \& Pieters, R. (2007). "Never eat in that restaurant, I did!": Exploring why people engage in negative word-of-mouth communication. Psychology \& Marketing, 24(8), 661-680.

Wien, A. H., \& Olsen, S. O. (2014). Understanding the relationship between individualism and word of mouth: A self-enhancement explanation. Psychology \& Marketing, 31(6), 416-425.

Yasin, M., \& Shamim, A. (2013). Brand love: Mediating role in purchase intentions and wordof-mouth. Journal of Business and Management, 7(2), 101-109. 